\title{
Rancangan Garap Karya Gending Sekar Jagad Berbasis Motif Batik Gaya Yogyakarta
}

\author{
Umilia Rokhani $^{1}$ dan Haryanto ${ }^{2}$ \\ ${ }^{1} J u r u s a n$ Musik, Fakultas Seni Pertunjukan, Institut Seni Indonesia Yogyakarta \\ ${ }^{2}$ Jurusan Etnomusikologi, Fakultas Seni Pertunjukan, Institut Seni Indonesia Yogyakarta
}

\begin{abstract}
The Musical Design of Gending Sekar Jagad Based on Batik Motif of Yogyakarta Style. The creation of works employing transforming media becomes an exciting breakthrough in the art industry to study. Using the concept of changing the media, the meeting of the two different media, such as art and music, provides opportunities for the emergence of a broader range of creative work. The design of musical works based on the inspiration and philosophy from the media of batik has complexity and beauty and high value as the great works from the Indonesian ancestors. Sekar Jagad is a title for the composition of musical design, taken from the name of a batik motif that is very familiar in Javanese culture. By understanding the basic batik motifs such as gringsing, kawung, machete, nitik, cement and poleng, the elements of vocal melodies performed in two different voices gave an overview of the concept of the Sekar Jagad batik motif. It indeed required knowledge of the shape, function and character of the batik motif itself as the basis for gending in musical arts. The melody arrangement was made entirely with two tunings or pelog and slendro scales. It was intended to find the characters that best suits the characteristics and philosophy of batik. The elements of batik motifs that were put together into one Sekar Jagad batik motif were then applied through vocal melodies and supported by lyrics that described some of these batik elements.
\end{abstract}

Keywords: art creation; media transformation; batik; gending; Sekar Jagad

\begin{abstract}
ABSTRAK
Penciptaan karya menggunakan alih wahana menjadi terobosan industri seni yang menarik untuk dikaji. Konsep ini dengan mempertemukan dua media yang berbeda yakni seni rupa dan seni musik sehingga memberikan peluang munculnya berbagai kreativitas berkarya yang lebih luas. Perancangan karya musik ini berdasarkan inspirasi dan filosofi dari media batik yang memiliki kerumitan sekaligus keindahan dan nilai yang tinggi sebagai karya besar peninggalan leluhur bangsa Indonesia. Sekar Jagad merupakan sebuah judul komposisi perancangan seni karawitan yang diambil dari sebuah nama motif batik yang sangat familiar dalam budaya masyarakat Jawa. Dengan corak motif batik dasar seperti gringsing, kawung, parang, nitik, semen dan poleng, unsur-unsur melodi vokal yang dilakukan dengan dua suara berbeda memberikan gambaran terhadap konsep motif dasar batik Sekar Jagad. Hal tersebut tentu saja memerlukan pengetahuan mengenai bentuk, fungsi dan karakter dari motif batik itu sendiri sebagai dasar penciptaan gending dalam karawitan. Penyusunan melodi dilakukan dengan dua laras atau sistem tangga nada pelog dan slendro. Hal ini dimaksudkan untuk menemukan karakter yang paling sesuai dengan karakter dan filosofi batik. Unsur-unsur motif batik yang disatukan dalam satu motif batik sekar jagad diaplikasikan melalui susunan melodi vokal dan didukung oleh lirik yang mendeskripsikan mengenai beberapa unsur batik tersebut.
\end{abstract}

Kata kunci: penciptaan; alih wahana; batik; gending; sekar jagad

1 Alamat korespondensi: Jurusan Musik, Fakultas Seni Pertunjukan, Institut Seni Indonesia Yogyakarta, Jalan Parangtritis Km. 6,5 Sewon Bantul, Yogyakarta.E-mail: umilia_erha@yahoo.co.id; HP.: 082221953779. 


\section{Pendahuluan}

Karya gending Jawa, baik gaya Solo maupun gaya Yogyakarta, yang telah dibuat oleh para empu karawitan masih sering didengar sampai sekarang. Terdapat keterlibatan kuat para musisi Jawa dalam membentuk identitas mereka sendiri melalui karya-karya yang dihasilkan sekalipun terdapat tekanan global, nasional, dan lokal yang harus mereka hadapi dalam upaya mempertahankan identitas melalui karya-karya tersebut (Cooper, 2015; Supriatna, 2010). Pada dasarnya sebagian besar gending tersebut telah dirancang oleh para pujangga atau empu dan disajikan secara ensambel yaitu instrumen dan vokal. Penciptaan atas gending tersebut tidak terlepas dari keberadaan gamelan. Gamelan merupakan ensambel seperangkat alat musik yang di dalamnya terkandung ide-ide dan terdapat ikatan berupa peraturan musik dan pemainnya (Syarif \& Hastuti, 2015). Pembagian fungsi instrumen gamelan terdiri dari: (1) kendang sebagai pengatur irama atau pengatur tempo, (2) demung dan slethem sebagai penanggung jawab balungan pokok, (3) rebab sebagai penghias dan penuntun melodi sinden (vokalis perempuan tunggal/solo), (4) ketuk, kenong, kempyang, kemong, gong adalah sebagai instrumen kolotomik yang memberikan ciri khas bentuk gending, dan (5) gender, saron, bonang, suling sebagai ornamen yang memperindah sebuah gending (Sumarsam, 1995). Adapun beberapa bentuk seni vokal di antaranya adalah gerongan, sindenan, bowo, senggakan dan alok. Gending diciptakan bukan hanya untuk sekedar didengarkan untuk kenikmatan tetapi juga sebagai sarana pendidikan sehingga syair dari nyanyian (gerong, bowo, sindenan) biasanya berisi tentang petuah dari guru kepada murid, cerita babad, sanjungan terhadap seseorang atau tokoh tertentu dan juga sindiran atau kritik sosial. Disamping itu bahwa gending memiliki kekuatan commonsense principle yang artinya bahwa kosmos bunyi gamelan mampu menembus jarak perbedaan kenyataan budaya, sikap hidup, kebiasaan dan lain sebagainya (Hardjana, 2004). Namun demikian hampir tidak ada atau sangat jarang syair dari beberapa jenis vokal tersebut yang membahas secara khusus tentang pengenalan seni batik.
Batik merupakan satu-satunya pakaian tradisional yang sangat erat hubunganya dengan karawitan. Secara terminologi, batik merupakan karya berbentuk gambar yang digoreskan dengan mempergunakan alat canting atau sejenisnya dan mempergunakan bahan lilin sebagai penahan masuknya warna. Sementara itu, ensiklopedia nasional Indonesia menyebutkan batik sebagai salah satu bentuk seni tradisional asli Indonesia yang dilakukan dengan menghias kain atau bahan lainnya dengan mempergunakan motif hiasan dan pewarna tertentu (Balik, 2015).

Antara batik dan karawitan ini dapat dikatakan hampir tidak pernah terpisahkan. Keduanya merepresentasikan kekhasan karakteristik tradisi. Identitas budaya yang dibawa dalam suatu pertunjukan dapat ditinjau dari kostum yang dikenakan saat pertunjukan. Dalam hal ini, kostum berperan untuk menjadi identitas kultural bahkan seringkali menjadi sudut pandang bagi pertunjukan yang akan dilakukan (Merlo, 2016). Pada pertunjukan karawitan, para penabuh atau pemain gamelan umumnya mengenakan pakaian yang bermotif batik. Hal ini membuktikan bahwa terdapat sinergi konsep pertunjukan yang tidak hanya sekadar membuat suatu konsep pertunjukan semata, tetapi juga berdampak pada pelestarian batik dan kesenian tradisi itu sendiri. Batik sendiri telah menjadi salah satu dari sepuluh unsur kebudayaan yang telah dikenal oleh masyarakat Jawa sejak zaman prasejarah (Sahlan \& Mulyono, 2012).

Dalam perkembangannya, batik tidak hanya digunakan oleh bangsa Indonesia tetapi karya seni adiluhung ini sudah lama dikenal oleh masyarakat di seluruh dunia sampai sekarang. Orang asing sudah lama mulai mempelajari seni batik, baik secara teori maupun praktik, sehingga tidak jarang dijumpai para wisatawan asing yang sangat paham dengan motif dan kualitas batik. Ironisnya bagi bangsa Indonesia sendiri jarang yang memahami motif dan kualitas batik termasuk dengan filosofi batik yang sebenarnya mengandung arti yang sangat dalam. Permasalahan ini bahkan terjadi pada berbagai kalangan yang setiap hari menggunakan kain batik. Mereka tidak mengerti nama atau jenis motif batik yang dipakai. Padahal terdapat motif 
batik yang dianjurkan untuk dipergunakan pada acara tertentu, seperti upacara pernikahan. Terdapat motif-motif batik yang dianjurkan untuk dikenakan dalam pernikahan, antara lain: motif grompol, motif truntum, motif sida lubur, dan motif sido mukti. Selain itu, terdapat beberapa motif batik yang tidak diperkenankan untuk dikenakan oleh masyarakat umum, seperti motif parang rusak barong, motif parang rusak gendreh, motif parang klithik, motif udan liris, motif rujak senthe, motif parang-parangan, motif cemungkiran, motif kawung, dan motif huk. Untuk itu, pengetahuan dalam penggunaan motif batik menjadi hal yang penting untuk diketahui dan dipelajari. Berbagai proses produksi seringkali dipergunakan untuk mendekatkan dan mengenalkan batik agar lebih dekat dengan masyarakat, seperti memproduksinya dalam berbagai bahan. Batik tidak lagi diproduksi diatas kain saja tetapi juga diproduksi pada berbagai bahan lainnya, seperti kertas untuk dibuat sebagai map, kaca untuk hiasan cermin atau gelas, dan menjadi bentuk kue yang bermotif batik. Selain itu, juga terjadi alih wahana, seperti batik sebagai bentuk permainan dengan mempergunakan perangkat teknologi/aplikasi (Purnamasari, Nugroho, \& Widian, 2017). Demikian pula halnya proses pengalihwahanaan dari batik menjadi bentuk gending ini juga menjadi bagian dari upaya pengenalan yang lebih dalam sekaligus pelestarian kedua karya seni tersebut. Menurut Sperber, proses pelestarian sebagai transmisi budaya dapat terwujud melalui dua cara, yaitu intra subjektif yang melibatkan ingatan dan pikiran, dan antar subjektif yang mewujud dengan adanya imitasi dan komunikasi. Sekalipun dalam proses pelestarian tentu saja tidak dapat memenuhi harapan secara mutlak karena keterbatasan ingatan manusia, bentuk-bentuk turunan imitasi yang tidak dapat sempurna, dan komunikasi-komunikasi yang terdistorsi dalam proses penyampaian pesan komunikasi. Hal yang harus dipahami bahwa ingatan manusia memiliki faktor-faktor kelemahan dan keterbatasan. Namun demikian, proses transformasi yang terjadi karena adanya interaksi budaya, apabila diakui dan dimaknai secara positif, tetap akan bernilai sebagai bentuk-bentuk kekayaan, kemajuan, dan berkonteks positif lainnya (Saearani, Simatupang, Soedarsono,
\& Kusmayati, 2014). Dalam hal ini, kebudayaan hanya akan terbentuk di tengah masyarakat dengan adanya proses human culture interaction yang kemunculannya terjadi, terpicu, dan terpengaruh karena adanya culture events (Junaidi, 2013).

Perubahan bentuk dari batik ke bentuk gending menunjukkan adanya alih wahana atas karya cipta manusia. Hal itu membutuhkan suatu rancang garap yang sesuai dan mampu merepresentasikan secara tepat dari bentuk batik ke bentuk gending. Definisi garap itu sendiri adalah kegiatan menafsir, mengolah, dan memikirkan suatu gending agar dapat disajikan dalam bentuk sajian yang estetis menurut kaidah-kaidah konvensional dalam karawitan (Subuh, 2016). Sementara itu, konsep alih wahana ini dimunculkan oleh Bluestone (1957) pada objek karya sastra menjadi bentuk novel. Dapat diketahui bahwa berbagai bentuk karya seni dapat menjadi teks yang mengacu pada proses bentuk alih wahana ini. Dalam hal ini, alih wahana yang terjadi merupakan proses pemindahan atau perubahan bentuk dari batik, khususnya motif sekar jagad, ke dalam musik berupa gending Jawa. Berdasarkan asal katanya, pengalihan wahana ini disebut dengan ekranisasi yang diartikan sebagai proses pelayarputihan (ecran dalam bahasa Prancis berarti layar) karena konsep ini muncul atas film. Lebih jauh, Eneste (1991) menyatakan bahwa ekranisasi merupakan proses perubahan pada alat yang dipakai, proses penggarapan, proses penikmatan, dan waktu penikmatan. Dengan demikian, dapat diketahui bahwa dari perubahan atas proses alih wahana tersebut terjadi perubahan pula atas fungsinya.

Perubahan atas alih fungsi tersebut perlu dikaji dengan mempergunakan teori intertekstual karena penciptaan atas gending Jawa tersebut berdasar pada keberadaan batik sekar jagad. Teori intertekstual dipergunakan untuk menganalisis transformasi bentuk dari batik ke musik. Teori intertekstual menganggap segala sesuatu, termasuk di dalamnya bentuk karya, sebagai teks (Ratna, 2005). Oleh karena itu, teori intertekstual menembus batas antardisiplin dan antarbentuk karya. Dengan mengkaji perubahan bentuk tersebut dapat diketahui pula perubahan fungsi yang terjadi sebagai hasil interpretasi. 
Menurut Culler, pemahaman atas konsep intertekstual berelasi dengan pemahaman atas proses pembacaan (Ratna, 2005). Proses pembacaan dan pemahaman terhadap teks, dalam hal ini adalah karya batik, menentukan posisi pembaca teks tersebut. Penikmat batik akan mengendapkan berbagai motif yang dinikmatinya dari batik sekar jagad ke dalam gudang memorinya. Posisi pembaca teks dalam hal ini berada pada posisi persimpangan antara ingatan dan harapan. Ingatan atas memori yang mengendap dalam gudang memori atas motif-motif sekar jagad sekaligus harapan untuk menciptakan gending yang memiliki proses khusus karena keinginan memunculkan dari motif-motif batik yang ada dalam ingatan. Dalam proses pencernaan atas teks, terdapat relasi imbal balik yang berpengaruh satu dengan lainnya antara ingatan dan harapan. Teks yang pernah diserap akan mengendap didasar ingatan penikmat karya dan endapan ingatan tersebut akan memasuki konteks pada karya baru yang beralih wahana yang mengubah sintesis masa lalu yang kemudian disusun ulang dan dimunculkan kembali sebagai ingatan saat membentuk karya baru yang mengalami transformasi (Iser, 1987).

Dari proses pembacaan tersebut terjadi berbagai proses, antara lain: pertama, recuperation (prinsip penemuan kembali). Proses penemuan kembali ini muncul melalui ide-ide yang terbentuk karena pengamatan atas berbagai motif yang muncul dalam motif sekar jagad. Kedua, naturalization yaitu prinsip untuk membuat yang semula asing menjadi biasa. Ide untuk menciptakan gending berdasarkan batik yang pada mulanya tidak selaras dalam bentuk tetapi menjadi selaras dengan melihat garis dan bunyi sebagai sesuatu yang sejajar. Ketiga, motivation yaitu prinsip penyesuaian, bahwa teks tidak arbitrer atau tidak koheren. Dengan melihat bahwa garis dan bunyi merupakan hal yang sejajar, dapat dicari sebuah persamaan, pengembangan, dan pengurangan melalui proses seleksi dan eksplorasi untuk penciptaan gending. Keempat, vraisemblation merupakan prinsip integrasi dari satu teks dengan teks atau sesuatu yang lain. Prinsip ini berupaya melihat berbagai motif yang dapat diintegrasikan sebagai unsur-unsur gending.
Istilah intertekstual pertama kali dimunculkan oleh Julia Kristeva yang melihat posisi suatu teks yang di dalamnya terdapat beberapa buah teks (Napiah, 1994). "Any text is reconstructed as mosaic of quotations; any text is the absorbtion and transformation of another" (Kristeva, 1987). Kaidah-kaidah yang dipergunakan dalam kajian inter tekstual, yaitu sebagai berikut. Pertama, inter tekstual melihat keberadaan teks yang didalamnya terdapat pada teks-teks lain yang pernah ada sebelumnya. Kedua, teks baru yang muncul karena adanya teks-teks terdahulu yang kemunculan teks baru tersebut menjadi suatu respon yang dapat berupa penerimaan ataupun penolakan terhadap teks-teks yang terdahulu yang mendasari kemunculan teks baru tersebut. Ketiga, menurut Bakhtin, intertekstual melihat pada unsur-unsur pembangun teks dapat berupa aspek dalam teks dan aspek luar teks. Keempat, inter tekstual juga mengkaji fungsi timbal balik antara aspek dalam dengan aspek luar teks sebagai dialog antara keduanya sebagai bentuk-bentuk atas respon yang dimunculkan (Kristeva, 1987).

Beberapa prinsip yang dapat dipergunakan dalam penerapan teori inter tekstual adalah sebagai berikut. Pertama, transformasi adalah penjelmaan, pemindahan, atau penukaran suatu teks ke teks yang lain. Penerapan unsur ini dapat dilakukan dengan dua cara, yaitu formal dan abstrak. Secara formal, transformasi adalah pemindahan, penjelmaan, atau penukaran teks secara keseluruhan atau hampir keseluruhan. Kedua, haplologi yaitu unsur inter tekstual berupa pengguguran, pembuangan, atau penghilangan sehingga tidak dapat untuk menghadirkan seluruh teks. Ketiga, ekserp yaitu unsur intert ekstual yang dalam penerapannya mengambil intisari dari sebagian episode, petikan, atau suatu aspek secara sama atau hampir sama dengan teks yang telah ada sebelumnya. Keempat, modifikasi yaitu penyesuaian atau perubahan suatu teks terhadap teks yang telah ada sebelumnya. Biasanya, prinsip ini dipergunakan dengan tujuan untuk melakukan penyesuaian, perbaikan ataupun pelengkapan dalam teks yang muncul kemudian berdasarkan pada teks yang telah ada sebelumnya. Pada umumnya, penyesuaian atau perubahan berlaku pada pemikiran, alur, atau gaya yang ingin 
dibangun dalam karya tersebut. Kelima, ekspansi adalah bentuk perluasan atau pengembangan terhadap suatu teks baru atas teks-teks lama (Napiah, 1994).

Batik merupakan warisan budaya Indonesia yang melekat sebagai salah satu identitas budaya Indonesia yang diakui dunia internasional sebagai Warisan Kemanusiaan untuk Budaya Lisan dan Tak Benda oleh UNESCO. Penggunaan batik di kalangan masyarakat Indonesia itu sendiri tidak asing lagi, tetapi masih sangat sedikit dari kalangan masyarakat Indonesia itu sendiri yang memahami berbagai motif batik yang seriang dikenakannya. Oleh karena itu, pemilihan sekar jagad sebagai motif yang dialihwahanakan ke dalam gending Jawa menjadi pilihan utama karena keberadaan motif ini akan merangkum dan memunculkan berbagai motif batik menjadi satu kesatuan motif. Alasan lain atas pemilihan batik untuk dialihwahanakan karena keberadaan batik sebagai kekayaan budaya Indonesia sebenarnya sejajar dengan keberadaan gending Jawa yang juga menjadi salah satu identitas budaya Indonesia.

Pada perancangan komposisi gending Sekar Jagad kali ini diharapkan dapat memberikan pemahaman tentang seni batik bagi para pelaku dan penikmat karawitan khususnya serta masyarakat Indonesia pada umumnya. Usaha memperkenalkan batik melalui karawitan bukanlah sesuatu yang mudah sehingga perlu didukung oleh berbagai pihak seperti misalnya seniman, budayawan dan instansi pemerintah yang berkompeten dalam bidang seni budaya.

\section{Metode Perancangan}

Komposisi ini merupakan perpaduan dari dua macam ide yaitu (internal) atas hasil renungan dan (eksternal) yang dilakukan atas fenomena sosial, kemudian dijabarkan secara tertulis dan menjadi sebuah konsep musikal yang didukung oleh tiga hal yaitu: ruang, waktu dan materi. Sebaliknya, sikap mental pendengar untuk mendengar, memahami, dan memberikan respon emosi atas garap rancang komposisi juga dipengaruhi unsur temporal, lokasi, pengalaman dan konteks budaya seseorang (Prasetya, Haryono, \& Simatupang,
2011). Di dalam proses perancangan akan selalu mempertimbangkan bentuk bunyi dan sifat bunyi sebagai sebuah kontrol untuk menghasilkan harmonisasi dan keindahan bunyi, seperti misalnya: teratur $><$ acak, tetap $><$ berubah, gaduh $><$ tenang, bersambung $><$ terputus, menyatu $><$ terpisah, besar $><$ kecil, rendah $><$ tinggi, lebar $><$ tipis, bulat $><$ pecah, berat $><$ ringan, panjang $><$ pendek, lurus $><$ lengkung.

Tentu saja bentuk dan sifat bunyi sulit ditelaah secara matematis, maka perancangan harus menggunakan tanda sedetail mungkin sehingga akan mempermudah penafsiran masing-masing pemain.

Langkah pertama adalah penulisan notasi melodi vokal dengan menggunakan notasi angka (kepatihan) yang biasa digunakan dalam karawitan Jawa. Didalam penulisan dan pencarian atau eksplorasi nada digunakan salah satu instrumen gamelan yang memiliki jangkauan nada yang sangat luas yaitu dua buah instrumen gender (pelog bem dan slendro). Kemudian penataan lirik yang diambil dari sumber tertulis dan hasil wawancara mengenai motif dan sejarah batik yang disesuaikan dengan susunan melodi. Setelah lagu vokal tersusun kemudian dilanjutkan dengan pembuatan melodi dasar (balungan) yang akan dimainkan oleh instrumen demung, saron dan slenthem. Balungan menunjang keberadaan suatu gending sebagai nada dasar atau inti dari komposisi (Teguh, 2017). Langkah kedua adalah pemberian tanda kolotomik (ketuk, kenong, kempul dan gong) yang akan menentukan bentuk gending serta penulisan notasi permainan masingmasing instrumen pamurba lagu vokal (rebab), pamurba lagu instrumen (bonang) dan pamurba irama (kendang). Setelah semua komposisi ditulis secara lengkap kemudian dilakukan eksperimen, yaitu dimainkan secara bersama satu ensambel yang terdiri dari instrumen gamelan lengkap dan vokal secara koor yang akan melibatkan 25 pemain. Dalam permainan komposisi gending yang dimainkan dengan gamelan, tidak terdapat seorang konduktor seperti halnya pada pertunjukan Musik Barat. Oleh karena itu, harmonisasi dan konsistensi kinerja dipertahankan oleh semua musisi bersama melalui persepsi tentang karakteristik suara yang dihasilkan oleh masing-masing instrumen 
gamelan (Suyatno, Tjokronegoro, Merthayasa, \& Supanggah, 2016).

Pada dasarnya bentuk gending ketawang Sekar Jagad tidak jauh berbeda dengan gending jenis ketawang yang lain seperti: Puspa Warno, Puspa Giwang, Suba Kastawa dan lainya tetapi ada beberapa garapan khusus dalam bagian umpak yang dimainkan dengan teknik imbal Demung. Pada bagian vokal digarap berbeda dengan gending tradisi yang lain, yaitu dinyanyikan secara koor yang akan membentuk sebuah harmoni sederhana yaitu dengan membagi dua suara atau digunakan istilah suara satu dan suara dua.

\section{Karakteristik Batik Sekar Jagad}

Motif sekar jagad berasal dari bahasa Jawa yaitu kata sekar dan kata jagad. Kata sekar berarti bunga; kata jagad berarti dunia. Namun kata sekar jagad juga dapat diangkat dari bahasa Belanda yaitu kata kar jagad (kar artinya peta; jagad artinya dunia) sehingga diartikan sebagai peta dunia (batik. or.id, 2014; Salma, Masiswo, Satria, \& Wibowo, 2015; Surya \& Tresna P., 2012). Batik sekar jagad sendiri termasuk jenis batik keraton, yaitu batik yang dirangkai dengan aturan dan budaya keraton. Keberadaannya sebagai batik keraton memiliki nilai filosofi yang berasal dari budaya Hindu-Budha yang berkembang dengan pola tradisional, terutama yang tumbuh berkembang di lingkungan kraton (Qoimah, 2012). Dengan menilik pada definisi kata 'sekar jagad', dapat diketahui bahwa motif sekar jagad cenderung mengarah pada penggambaran ragam flora (bunga dan tumbuhan) dan dunia sehingga membentuk suatu gabungan komposisi ornamen-ornamen geometris yang disusun dengan berbagai motif batik yang menarik.

Pada motif sekar jagad terdapat perpaduan antara garis, bentuk, dan isen. Motif sekar jagad gaya Yogyakarta mempergunakan bentuk garis yang bergelombang, berbelok, atau berliku. Isian motif sekar jagad gaya Yogyakarta pada umumnya berupa bentuk motif kawung, semen, truntum, grompol, parang, kupu, nitik cakar, gringsing dan ceplok. Batik motif sekar jagad Yogyakarta memiliki karakter motif yang berbeda dengan motif sekar jagad yang ada di daerah lain.

\section{Rancang Garap Gending Sekar Jagad Berbasis Motif Batik Gaya Yogyakarta}

Komposisi Gending Sekar Jagad terdiri dari tiga bagian yang masing-masing memiliki karakter berbeda. Bagian I, yaitu bagian awal setelah buka (introduksi) dimaksudkan untuk menciptakan suasana tegas dan agung. Suasana tersebut ditransformasi dari bentuk garis dari garis motif sekar jagad yang tegas dan berliku. Penjelmaan garis yang tegas menunjukkan bentuk keagungan dari introduksi yang dibentuk dalam kesan agung terhadap komposisi gending tersebut. Sementara itu, garis berliku diekspansi ke dalam gending dengan lengkung irama yang dimunculkan dalam bentuk komposisi berbagai instrumen di dalamnya. Pada bagian ini dimainkan dengan teknik tabuhan soran, artinya dimainkan secara keras dan tempo cepat yang lebih dikenal dalam karawitan sebagai irama 1 atau irama lancar. Kesan agung dimunculkan dengan unsur ekserp melalui pengambilan inti instrumen yang dijadikan instrumen pokok untuk menunjukkan bunyi keras dan tempo yang cepat. Instrumen yang dimainkan tidak berasal dari semua instrumen, hanya beberapa instrumen seperti: bonang barung, bonang penerus, demung, saron, peking, kenong japan, kempul manis, gong dan kendang kaleh (bedug dan ketipung). Instrumen bonang pada bagian ini dimainkan dengan menggunakan teknik mipil lombo, artinya setiap dua pukulan saron terdiri dari empat pukulan bonang. Permainan instrumen-instrumen tersebut menjadi bentuk ekserp melalui permainan kombinasi dari instrumen saron dan bonang. Pemilihan instrumen bonang dan konsep kombinasi permainannya menunjukkan unsur modifikasi atas representasi komposisi ornamen batik sekar jagad.

Bagian ke-II atau umpak dimainkan dalam tempo lambat, yang di dalam karawitan dinamakan irama 2. Pemilihan tempo lambat menjadi bentuk modifikasi dari motif-motif batik yang menggambarkan perpotongan-perpotongan dari motif nitik dan motif parang yang terpotong dan miring. Dengan adanya perpotongan garis dan garis miring yang membentuk diagonal mengharuskan untuk menghadirkan tempo yang bersifat lambat. Dengan menekankan pada perpotongan garis dari 
motif nitik dan keberadaan garis miring pada motif parang, unsur haplologi yang menghilangkan unsur lain dari motif batik menjadi pilihan untuk dialihwahanakan menjadi irama gending. Jenis instrumen yang dimainkan sama dengan bagian I tetapi tabuhan instrumen demung dimainkan dengan menggunakan teknik imbal, sedangkan instrumen bonang dimainkan dengan teknik mipil rangkep artinya setiap dua pukulan saron terdiri dari delapan pukulan bonang. Penggunaan tempo lambat dimodifikasi dengan teknik permainan yang estetis menghasilkan pembauran permainan dua instrumen yang menarik untuk membuat permulaan masuknya ke bagian III.

Bagian III merupakan bagian inti yang digarap secara lirihan atau halus dengan menambahkan permainan instrumen lain seperti: gender, rebab, gambang dan vokal. Bentuk modifikasi dan transformasi berbagai instrumen dan vokal menjadi bentuk pengayaan dan pelengkapan sebagai penandasan pada bagian inti dari gending ini. Pada bagian III terdiri dari dua gongan atau dua melodi gending. Modifikasi dengan membuat dua alur melodi gending menjadi bentuk pengayaan dari motif batik sekar jagad. Notasi gending Sekar Jagad yang telah tersusun tersebut dilengkapi dengan beberapa notasi instrumen balungan (demung, saron, slenthem), notasi kendang, notasi imbal demung, notasi bonang, dan vokal. Dalam penciptaan gending ini, kebaruan melalui pengalihwahanaan batik ke gending lebih ditekankan pada warna melodi pada gending ini. Di samping itu, pada bagian ini juga disajikan beberapa simbol instrumen kolotomik, seperti ketuk, kenong, kempul dan gong dimaksudkan untuk lebih mempermudah bagi para penabuh pemula. Berikut notasi garap gending Sekar Jagad. Buka: .22 . $3123 \quad .122602222$

$$
\mathrm{t} \mathrm{t} \mathrm{p} \text { b } \cdot \mathrm{t} \mathrm{pb}
$$

$$
\begin{array}{cccccccc}
6 & 5 & 3 & 2 & 1 & 2 & 3 & 5 \\
\cdot & \mathrm{t} & \mathrm{p} & \mathrm{b} & \cdot & \mathrm{t} & \mathrm{p} & . \\
2 & 3 & 5 & \frac{6}{\mathrm{~T}} & 3 & 5 & 3 & 2 \\
\mathrm{p} & \mathrm{b} & \cdot \underset{\mathrm{tp}}{\mathrm{N}} & \mathrm{p} & \mathrm{p} & \mathrm{p} & \mathrm{b}
\end{array}
$$

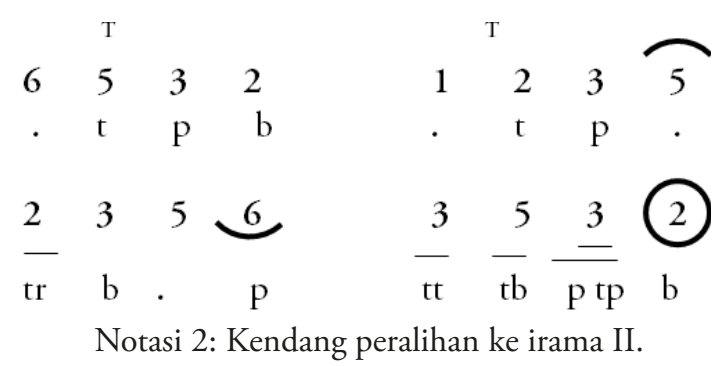

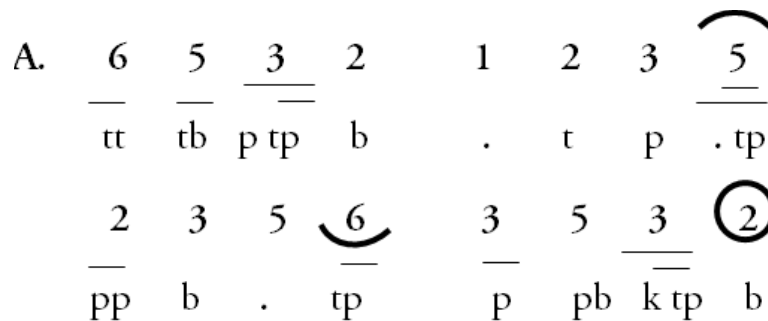

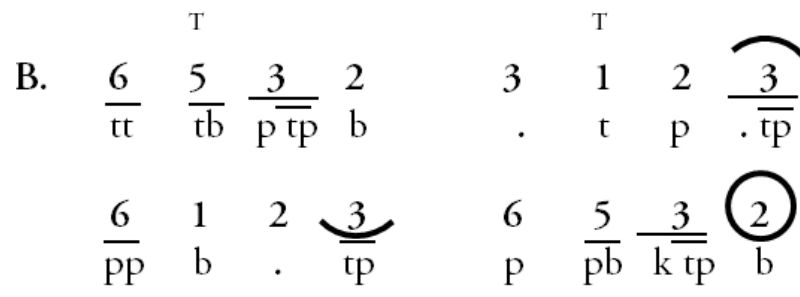
Notasi 3: Kendang irama II.

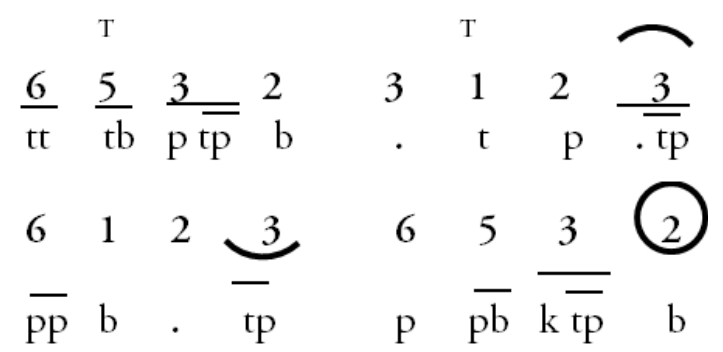

Notasi 4: Ompak (garap soran).

Dm $2.6 .6 .6 .5 \quad .3 .3 .3 .2$

$\operatorname{Dm} 15.5 .5 .5 .2 .2 .2 .2$.

$\operatorname{Dm} 2.2 .2 .2 .1 \quad .5 .5 .5 .3$

$\operatorname{Dm} 1$ 1.1.1.1. 3.3.3.3.

$\operatorname{Dm} 2.2 .2 .2 .1 \quad .5 .5 .5 .3$

$\operatorname{Dm} 1$ 1.1.1.1. 3.3.3.3.

$\operatorname{Dm} 2 . .6 .6 .6 .5 .3 .3 .3 .2$

$\operatorname{Dm} 15$. 5 . 5 . 5.5 2.2.2.2. Notasi 5: Imbal demung. 


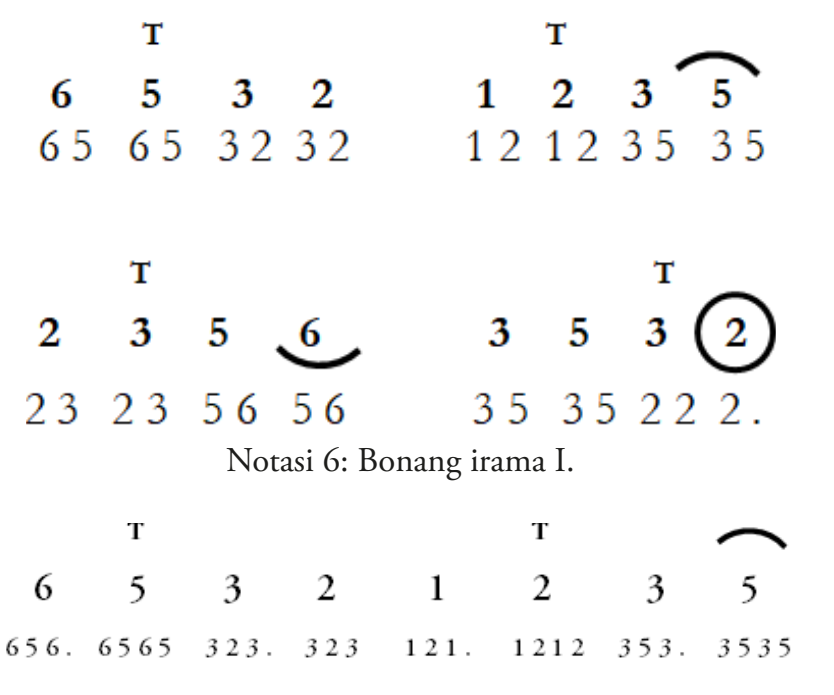

$\begin{array}{cccccccc}2 & 3 & 5 & 6 & 3 & 5 & 3 & 2 \\ 232.2323 & 565 . & 565 & 353 . & 3535 & 222 . & 22 \ldots\end{array}$

$\begin{array}{rrcccccc} & & & & & & & \\ 6 & 5 & 3 & 2 & 3 & 1 & 2 & 3 \\ 3336 & 3565 & 321 . & 3212 & 333 . & 33 \ldots & 333 . & 33 \ldots\end{array}$

$\begin{array}{cccccccc}6 & 1 & 2 & 3 & 6 & 5 & 3 & 2 \\ 616 . & 6161 & 232 . & 2323 & 656 . & 6565 & 222 . & 22 . \\ \text { Notasi 7: Bonang irama II. }\end{array}$

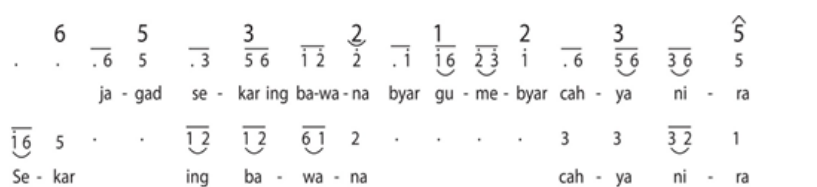

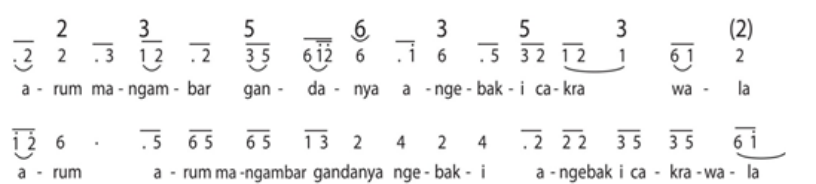

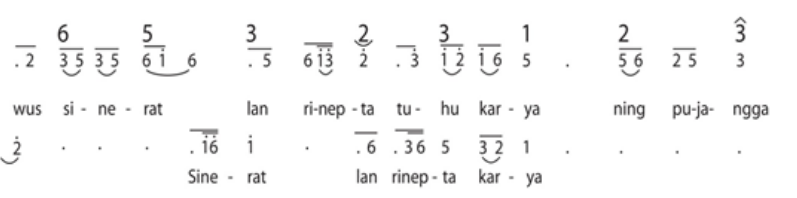

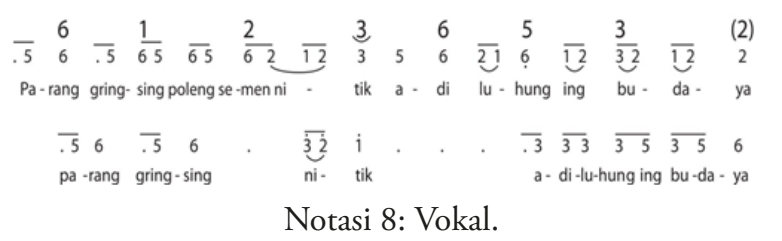

Jagad sekaring bawono, byar gumebyar cahyanira Arum mangambar gandanyo, angebaki cakrawala Wus sinerat lan rinepta, tuhu karyaning pujangga Parang grinsing semen poleng nitik, adilubung ing budaya

Sekar jagad bunga alam semesta, gemerlapan cahayanya Harum wangi aromanya, memenuhi cakrawala
Sudah tertulis dan tercipta, benar karya seorang pujangga Motif parang, gringsing, semen, poleng dan nitik, sebuah budaya yang bernilai tinggi

Syair ini menunjukkan bahwa sekar jagad menjadi penggambaran semacam bunga yang keindahannya dapat dinikmati di seantero dunia. Dalam setiap gending, akan terepresentasikan nilai rasa yang dibawakan apabila gending dimainkan sesuai dengan garapnya dan disajikan oleh pengrawit yang menguasai gending tersebut (Prasetya \& Susanto, 2016; Purwanto, 2010). Dari syair tersebut terlihat bahwa gending tersebut menunjukkan nilai gembira dan bangga terhadap keindahan sekar jagad tersebut. Semua orang dapat menikmati keharuman dan keelokan yang terpancar dari bunga tersebut. Hal yang demikian pula hakikatnya dengan sebuah gending yang ditulis dan diciptakan oleh sang pujangga. Karya merupakan wujud dari cipta, rasa, dan karsa manusia yang muncul dari serangkaian ide dan gagasan yang mengalami proses pengendapan, perenungan, penyeleksian, dan peng evaluasian sehingga muncul sebagai karya besar yang dapat dinikmati oleh semua penikmatnya. Dalam konteks karya ini, gagasan muncul dari keberadaan motif sekar jagad yang terwakili dengan keberadaan motif parang, gringsing, semen, poleng, dan nitik. Seperti halnya, dengan gending itu sendiri, motif-motif batik ini juga merupakan sebuah budaya yang merupakan hasil karya cipta manusia yang bernilai tinggi dan tidak lekang oleh zaman. Karya seni tersebut merupakan warisan para leluhur yang merepresentasikan pesan-pesan adiluhung (bijak) agar generasi penerusnya memiliki sikap menghormati atas keragaman dan menciptakan suatu harmoni (Widodo, 2015). Demikian pula yang tersirat dari kombinasi motif batik sekar jagad yang mencerminkan keberagaman berbagai motif yang dipadukan sehingga membentuk suatu harmoni keindahan suatu motif batik.

\section{Garap Melodi Gending Sekar Jagad Hasil Transformasi Motif Batik}

Melodi vokal pada gending ini dapat digambarkan melalui dua warna vokal, yaitu coklat tua sebagai melodi vokal suara satu, sedangkan coklat muda sebagai melodi untuk vokal suara dua. 
Pemilihan dua warna coklat muda dan coklat tua disamping untuk membedakan kedua suara juga dimaksudkan untuk merepresentasikan bahwa warna coklat identik dengan warna soga yang biasa digunakan dalam membatik. Kemudian gambar titik besar perpaduan dari dua warna coklat tua dan coklat muda merupakan titik pertemuan nada yang sama antara vokal suara 1 dan suara 2. Peta gambar yang dihasilkan perpaduan dua unsur warna suara tersebut menghasilkan beberapa bentuk garis, seperti titik, garis vertikal, garis horisontal, garis diagonal dan lengkung. Garis-garis ini juga muncul pada berbagai motif batik sekar jagad. Penataan garispun ada beberapa bentuk misalkan berurutan, bergerombol, acak dan menyebar. Kemudian setelah digabungkan, kedua vokal pada kedua bagian seperti dalam gambar akan membentuk motif dasar batik seperti: parang, gringsing, semen, poleng dan nitik. Dari unsur dasar tersebut kemudian dikembangkan menjadi motifmotif yang sangat banyak dan bervariasi. Gambar 1 merupakan hasil peta gambar notasi sebagai bentuk garis-garis melodi yang merepresentasikan unsurunsur motif sekar jagad.

Gambar Melodi Vokal.

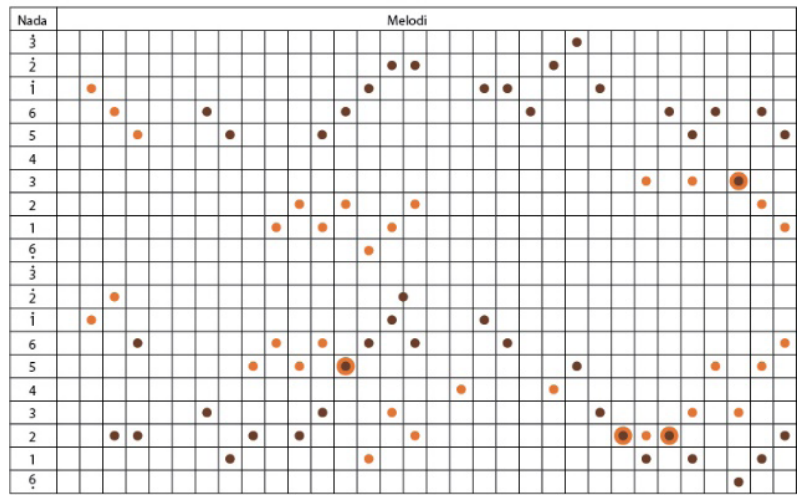

Gambar Melodi Vokal.

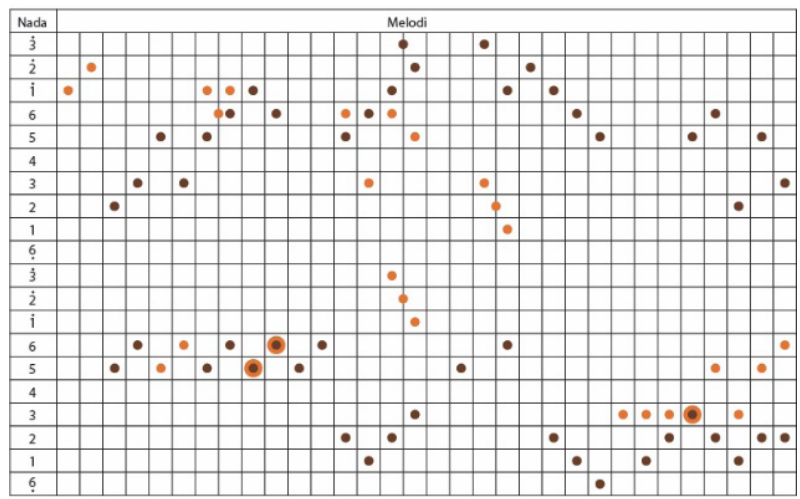

Gambar 1: Peta gambar melodi vokal.

\section{Kesimpulan}

Garis dan bunyi merupakan dua hal yang berbeda. Namun keduanya memiliki sifat yang sama atau dapat dikatakan bahwa keduanya merupakan bentuk titik dan garis. Perbedaan dari keduanya terletak pada gambar atau garis-garis yang membentuk motif batik Sekar Jagad dan motif batik yang lain adalah sebagai garis visual; sedangkan garis-garis dalam bunyi dan suara merupakan garis imajiner. Namun kemiripan sifat dari bentuk titik dan garis, baik yang visual maupun yang imajiner, menjadi dasar gagasan penciptaan rancang garap gending Sekar Jagad. Gending ini terbagi menjadi tiga bagian yang dilengkapi dengan olah vokal yang memaparkan lirik mengenai keindahan dan kemegahan sekar jagad yang dapat dinikmati oleh dunia sebagai karya yang bernilai adiluhung.

\section{Kepustakaan}

Balik, A. (2015). Implementasi Penerapan Pasal 38 Undang-Undang Nomor 28 Tahun 2014 Tentang Hak Cipta sebagai Upaya Perlindungan Hukum Karya Seni Batik. $S$ a s I, 21(1), 57-65.

batik.or.id. (2014). Makna dan Filosofi Batik Sekar Jagad. Retrieved June 5, 2020, from https:// batik.or.id/makna-dan-filosofi-batik-sekarjagad/

Bluestone, G. (1957). Novels into Film. Berkeley and Los Angeles: University of California Press.

Cooper, N. I. (2015). Returning Javanese Identities: The Ironies of a Popular Genre. Asian Music, 46(2), 55-88,145. Retrieved from https:// search.proquest.com/docview/1691586168 ?accountid $=38628$

Eneste, P. (1991). Novel dan Film. Flores: Penerbit Nusa Indah.

Hardjana, S. (2004). Musik antara Kritik dan Apresiasi. Jakarta: Penerbit Buku Kompas.

Iser, W. (1987). The Act of Reading: A Theory of Aesthetic Response. London: The Johns Hopkins Press Ltd.

Junaidi, A. A. (2013). Janengan sebagai Seni Tradisional Islam-Jawa. Walisongo: Jurnal 
Penelitian Sosial Keagamaan, 21(2), 469. https://doi.org/10.21580/ws.2013.21.2.254

Kristeva, J. (1987). Desire in Language: A Semiotics Approach to Literature and Art. England: Basil Blackwell Ltd.

Merlo, M. (2016). Traje de Tradição: Elementos da Contemporaneidade na Cultura de Rua. Moda Palavra E-Periódico, 9(18), 57-71.

Napiah, A. R. (1994). Tuah-Jebat dalam Drama Melayu: Suatu Kajian Intertekstualiti. Kuala Lumpur: Dewan Bahasa dan Pustaka Kementerian Pendidikan Malaysia.

Prasetya, H. B., Haryono, T., \& Simatupang, L. L. (2011). Habitus, Ngêng, dan Estetika Bunyi Mlèsèt dan Nggandul pada Karawitan. Paradigma: Jurnal Kajian Budaya, 1(2), 152 167.

Prasetya, H. B., \& Susanto, A. (2016). Mleset dalam Karawitan: Kasus pada Gending Pangkur. Gelar: Jurnal Seni Dan Budaya, 8(2), 168-178. https://doi.org/10.33153/ glr.v8i2.1327

Purnamasari, E., Nugroho, E. W., \& Widian, A. D. (2017). The Introduction of Classic Batik Motif to the Community Through Game. Journal of Information System: SISFORMA, 4(1), 31-36.

Purwanto, J. (2010). Ricikan Kethuk pada Karawitan Jawa Gaya Surakarta. Gelar: Jurnal Seni Dan Budaya, 8(2), 207-218.

Qoimah, H. (2012). Karakteristik Batik Motif SekarJagad Yogyakarta. Yogyakarta.

Ratna, N. K. (2005). Sastra dan Cultural Studies: Representasi Fiksi dan Fakta. Yogyakarta: Pustaka Pelajar.

Saearani, M. F. T. bin, Simatupang, G. L. L., Soedarsono, R. M., \& Kusmayati, A. M. H. (2014). Cultural Transformation Processes in the Current Development of YogyakartaStyle Classical Dance. International Journal for Innovation Education and Research, 2(04), 134-141. Retrieved from http:// www.ijier.net/assets/cultural-transformationprocesses-in-the-current-development-ijier. net-vol-2-4_12.pdf

Sahlan, A., \& Mulyono. (2012). Pengaruh Islam terhadap Perkembangan Budaya Jawa: Tembang Macapat. El Harakah: Jurnal Budaya Islam, 14(1), 101-114.

Salma, I. R., Masiswo, Satria, Y., \& Wibowo, A. A. (2015). Pengembangan Motif Batik Khas Bali. Dinamika Kerajinan dan Batik: Majalah Ilmiah, 32(1), 23-30.

Subuh. (2016). Garap Gending Sekaten Keraton Yogyakarta. Resital: Jurnal Seni Pertunjukan, 17(3), 178-188.

Sumarsam. (1995). Gamelan: Cultural Interaction and Musical Development in Central Java. Chicago: The University of Chicago Press.

Supriatna, E. (2010). Fungsi Seni Gembyung dalam Kehidupan Masyarakat Panjalu Kabupaten Ciamis. Patanjala, 2(3), 394-410.

Surya, M. C., \& Tresna P., P. (2012). Sekar Jagad in Victorian Style. Fesyen Perspektif, Vol 1, No.

1. Retrieved from ejournal.upi.edu

Suyatno, S., Tjokronegoro, H. A., Merthayasa, I. G. N., \& Supanggah, R. (2016). Analysis of Onstage Acoustics Preference of Musicians of Traditional Performance of Javanese Gamelan Based on Normalized Autocorrelation Function. Journal of Engineering and Technological Sciences, 48(5), 571-583. https://doi.org/10.5614/j.eng.technol. sci.2016.48.5.5

Syarif, A. M., \& Hastuti, K. (2015). Identifikasi Fitur Melodi Gending Lancaran Berdasarkan Pengenalan Pola Notasi. Techno.com, 14(3), 234-241.

Teguh. (2017). Ladrang Sobrang Laras Slendro Patet Nem. Resital, 18(2), 103-112.

Widodo. (2015). Laras in Gamelan Music's Plurality. Harmonia: Journal of Arts Research and Education, 15(1), 34-45. https://doi. org/10.15294/harmonia.v15i1.3695 